\title{
UTJECAJ ODABRANIH USLUGA HRATSKIH PODUZETNIČKIH INKUBATORA NA NJIHOVU USPJEŠNOST
}

\author{
Bojan Morić Milovanovićc ${ }^{4}$ \& Željka Tutić 5
}

\author{
UDC / UDK: 658.1:005.342(497.5) \\ JEL classification / JEL klasifikacija: L26, M13 \\ DOI: https://doi.org/10.22598/pi-be/2021.15.2.23 \\ Original scientific paper / Izvorni znanstveni rad \\ Received / Primljeno: September 19, 2021 / 19. rujna 2021.
}

Accepted for publishing / Prihvaćeno za tisak: November17, 2021 / 17. studenog 2021.

\section{Sažetak}

Poduzetnički inkubatori ubrajaju se u poduzetničke potporne institucije koji imaju za cilj pružiti podršku malim i srednjim poduzećima, posebice poduzetnicima početnicima. Njihovo osnivanje najčešće je rezultat inicijativa lokalne i regionalne razine te su po pravnome obliku uspostavljeni kao poduzeća u vlasništvu jedinica lokalne $i$ područne (regionalne) samouprave. Sobzirom na rasprostranjenost inkubatora i njihove uloge u gospodarskom razvoju, važno je istražiti uspješnost inkubatora u obavljanju osnovnih zadaća te ispunjavaju li ciljeve zbog kojih su osnovani. Poduzetnički inkubatori svojim poduzećima stanarima nude razne usluge, kao što su: usluge subvencioniranog najma poslovnog prostora, usluge poslovnog savjetovanja, usluge umrežavanja $i$ olakšavanja pristupa izvorima financiranja, te se pokazalo kako su usluge koje inkubatori pružaju pozitivno povezane s uspješnošću inkubatora. Stoga, cilj ovog rada je pomoću višestruke hijerarhijske regresije te Spearmanovog koeficijenta korelacije ranga ocijeniti utjecaj odabranih usluga na uspješnost poslovnih inkubatora u Republici Hrvatskoj. Rezultati potvrđuju povezanost većine usluga s uspješnošćcu, međutim pozitivan utjecaj na uspješnost imaju isključivo financijske usluge, te usluge umrežavanja.

Ključne riječi: poduzetnički inkubator; poduzetničke potporne institucije; poduzetnici početnici; usluge inkubatora; uspješnost.

\footnotetext{
${ }^{4}$ Izv. prof. dr. sc. Bojan Morić Milovanović, Viši znanstveni suradnik, Institut za javne financije, Zagreb, Hrvatska, E-mail: bojan.moric@ijf.hr 5 Željka Tutić, mag. pol., Voditelj odjela za koordinaciju Vijeća ECOFIN, Ministarstvo financija, Zagreb, Hrvatska, E-mail: zeljka.tutic@mfin.hr
} 


\section{UVOD}

Inkubatori su poduzetničke potporne institucije koje imaju ulogu u pružanju podrške poduzećima u ranoj fazi njihovog razvoja. U Republici Hrvatskoj prvi se inkubatori osnivaju nakon 1990-ih i predstavljaju stoga relativno noviji fenomen. Međutim, u promatranom razdoblju njihov se broj povećavao te ih danas ima šezdesetak. Oni se u najvećem broju osnivaju kao poduzeća u vlasništvu jedinica lokalne i područne (regionalne) samouprave (JLP(R)S) i neprofitnog su karaktera. Od 1990-ih godina koncept poslovnog inkubatora u svijetu proširio se od fizičkog prostora s osnovnim resursima do pružatelja usluga s dodanom vrijednosti, poput profesionalne poslovne podrške, savjetovanja, te stvaranja poduzetničkih mreža namijenjenim poduzetnicima početnicima (Tang i sur., 2014). Mulolli, Islami i Skenderi (2017) navode da je osnovni cilj poslovnih inkubatora povećati šanse za uspjeh poduzetnika početnika stvaranjem poticajnog okruženja s obzirom na probleme s kojima se suočavaju novoosnovana poduzeća. S druge strane, i poduzetnički inkubatori se u svome poslovanju također suočavaju s određenim problemima, kao što su: neiskustvo u upravljanju inkubatorom, nedovoljno kvalificirani zaposlenici inkubatora, premali prostor potreban za kvalitetno poslovanje, uspostava inkubatora izvan ekonomskih zona, nedostatak financiranja i ostalo (Mulolli, Islami i Skenderi, 2017; Sofouli i Vonortas, 2007; Tang i sur., 2014).

Također se susreću i primjeri inkubatora kojima upravljaju poduzeća iz privatnog sektora. Sofouli i Vonortas (2007) u studiji o razvoju znanstveno-tehnoloških parkova i poslovnih inkubatora u Grčkoj pišu kako se osnivanje i razvoj poslovnih inkubatora te znanstveno-tehnoloških parkova sve više kreće u smjeru što veće participacije privatnog sektora, pri čemu privatna poduzeća, uz podršku javnih sredstava, osnivaju i upravljaju navedenim institucijama s ciljem ostvarivanja profita. Tang i sur. (2014) utvrdili su razlike u uspješnosti između visoko-tehnoloških inkubatora kojima upravlja država i onih inkubatora u čije upravljanje su uključena privatna poduzeća. Utvrdili su kako su inkubatori kojima upravlja država manje učinkoviti u pružanju određenih usluga, poput poslovnog savjetovanja, financiranja i umrežavanja, te su zaključili kako osnovni razlog leži u činjenici da zaposlenicima inkubatora nedostaju potrebna poslovna i tehnološka znanja. Stoga, Tang i sur. (2014) smatraju kako veća uključenost privatnog sektora u upravljanje inkubatorima pridonosi uspješnijim procesima inkubacije i razvoja poduzetništva.

Inkubatori svojim stanarima pružaju širok raspon usluga, od usluga subvencioniranog najma poslovnog prostora, usluga poslovnog savjetovanja, usluga umrežavanja, sve do olakšanog pristupa izvorima financiranja. Iako najam poslovnog prostora i dalje ostaje osnovno obilježje, u novije se vrijeme usluge poslovnog savjetovanja ističu kao dodana vrijednost i razlog ulaska u inkubator. Razumijevanje uspješnosti inkubatora važno je kako bi se bolje razumjela njihova uloga u pružanju podrške novoosnovanim poduzećima i njihov doprinos gospodarskom razvoju. Istraživanja su pokazala kako postoji pozitivan odnos između ponude određenih usluga od strane inkubatora (Batlle, 2016; Li i sur., 2020) i uspješnosti inkubatora, te se u ovome radu nastoji dodatno ispitati postojanje povezanosti između navedenih varijabli. Stoga, na temelju pregleda literature odabrane su sljedeće usluge koje se dovode u vezu s 
uspješnošću inkubatora: infrastrukturne usluge, financijske usluge, usluge umrežavanja, pravne usluge, usluge upravljanja ljudskim resursima, te usluge poslovnog savjetovanja (Abduh i sur, 2007; Wang i sur, 2008; Sarwono i Triestyarso, 2017).

\section{PREGLED LITERATURE I HIPOTEZE}

Poduzetnički inkubatori pružaju podršku malim i srednjim poduzećima u prvim godinama nakon njihova osnivanja. U razdoblju koje je najosjetljivije za njihov opstanak i razvoj poduzećima je na raspolaganju logistička podrška te potrebni savjeti. U poslovnim inkubatorima poduzetnicima početnicima su osim poslovnog prostora po povoljnoj cijeni, dostupne i razne druge profesionalne usluge, poput administrativnih usluga, računovodstvenih usluga, savjetovanja u vođenju i upravljanju poslovanjem, i dr. Korištenje poslovnog prostora moguće je po povoljnim uvjetima, ali je ograničeno na određeno razdoblje, obično do tri ili pet godina. Ovo pravilo međutim može biti i vrlo fleksibilno i omogućiti poduzećima da i po isteku ograničenog razdoblja boravka i dalje ostanu unutar inkubatora (Sofouli i Vonortas, 2007). Mijačić (2011) navodi da je takav način ograničenja duljine mogućeg boravka korisnika u poslovnome inkubatoru u funkciji njihovog što bržeg osamostaljivanja kao i oslobađanja prostora za nove korisnike poslovnog inkubatora.

Van Weele, Van Rijnsoever i Nauta (2017) u svojem istraživanju razlika u percepcijama poduzetnika početnika i inkubatora glede koristi resursa i usluga koje inkubatori pružaju, došli su do zaključka kako vrlo često u početnim fazama poduzetnici ne percipiraju koristi raznih programa poslovnog obrazovanja i usavršavanja koje inkubator pruža, već to postupno uviđaju. Stoga, Bošnjak (2011) smatra kako je važno da poduzeća stanari prepoznaju koristi od usluga poslovnog savjetovanja koje su im na raspolaganju, te kako je za njihov uspjeh iznimno bitno da i koriste te usluge u svom svakodnevnom poslovanju. Rice (2002) navodi različite pristupe koje inkubatori mogu slijediti u pružanju usluga poslovnog savjetovanja, među kojima su: (i) reaktivno i epizodno savjetovanje, (ii) proaktivno i epizodno savjetovanje, te (iii) kontinuirano i proaktivno savjetovanje. Reaktivno i epizodno savjetovanje odnosi se na inicijativu poduzeća stanara koje traži pomoć u rješavanju određenog problema ili krize. Proaktivno i epizodno savjetovanje uobičajeno pokreće voditelj inkubatora angažirajući poduzetnike u neformalnom, ad-hoc savjetovanju. Kontinuirano i proaktivno savjetovanje provodi inkubator na način da su poduzeća stanari pod stalnom revizijom i intervencijom voditelja inkubatora.

Djelatnosti inkubatora, kako navode Tupek i Čorić (2018) mogu se podijeliti u tri faze: (i) pred-inkubacija, koja označava razdoblje potrebno za razvoj poduzetničke ideje, pripremu i osnivanje poslovnog subjekta; (ii) inkubacija, koja označava fazu podupiranja poduzetnika od pokretanja posla ili osnivanja poduzeća do njegova širenja; te (iii) post-inkubacija koja uključuje djelatnosti nakon što je poduzeće dostiglo zreli stupanj razvoja i spremno je za samostalno poslovanje. U fazi pred-inkubacije, fokus je stavljen na odabir onih poduzeća stanara kojima se želi pružiti podrška u razvoju poslovne ideje, odnosno poslovnog plana. U fazi inkubacije, fokus je stavljen na pružanje niza 
potpornih usluga poduzećima, od njihovog osnivanja sve do faze poslovnog rasta, kako bi u suradnji s drugim akterima i organizacijama bili u mogućnosti ostvariti svoje poslovne ciljeve. Zaključno, u post-inkubacijskoj fazi, koja obuhvaća poduzeća koja su spremna na izlazak iz inkubatora, fokus je stavljen na aktivnosti kao što su: radionice, aktivnosti poslovnog umrežavanje, te razni oblici potpora vezanih uz izvozne aktivnosti ili aktivnosti razvoja inovacija.

Usluge koje pružaju poduzetnički inkubatori najčešće se klasificiraju u sljedeće skupine: (i) infrastrukturne usluge; (ii) savjetodavne usluge; (iii) usluge umrežavanja i (iv) financijske usluge (Batlle, 2016; CSES, 2002; OECD, 1997). Pri tome, financijske usluge često se smatraju dijelom usluga umrežavanja, budući da za cilj imaju povezivanje poduzeća stanara s potencijalnim investitorima (Batlle, 2016). U skladu s navedenom klasifikacijom, u nastavku teksta prikazane su tri osnovne skupine usluga poduzetničkih inkubatora.

\subsection{Infrastrukturne usluge}

Jedno od osnovnih obilježja poduzetničkih inkubatora je osiguravanje poslovnog ili radnog prostora svojim poduzećima stanarima. Pored poslovnog ili radnog prostora, među osnovne infrastrukturne usluge ubrajaju se još i pristup internetu, usluga čajne kuhinje ili kantine, mogućnost korištenja sobe ili dvorane za sastanke, pružanje informatičke opreme i namještaja za rad, usluga tajništva ili recepcije, te u slučaju specijaliziranih inkubatora pružanje tehnoloških prostora kao što su laboratoriji i istraživačke jedinice (Batlle, 2016; Bošnjak, 2011; CSES, 2002). Tehnološki inkubatori mogu imati svoje laboratorije, premda najčešće pristup laboratorijima osiguravaju kroz partnerstva sa sveučilištima ili znanstveno-tehnološkim parkovima te povezivanjem s istraživačkim odjelima poduzeća (OECD, 1997, Tang i sur, 2014).

Poduzetnički inkubator obično se sastoji od većeg broja manjih poslovnih jedinica na jednom mjestu koje su na raspolaganju poduzetnicima i poduzetnicima početnicima po povoljnijim uvjetima najma od tržišnih (Bošnjak, 2011). CSES (2002) u svome istraživanju navodi kako većina inkubatora nastoji osigurati prostor za najmanje dvadeset poduzeća stanara, kao i osigurati dostupnost različitih tipova prostora, od uredskog prostora do prostorija za zajedničke sadržaje. Korištenje zajedničkih prostorija i infrastrukture potiče poduzeća stanare na povezivanje i suradnju (Bošnjak, 2011). Brojni inkubatori nude usluge dijeljenog ili otvorenog radnog prostora kao dodatnu uslugu kojom proširuju svoju ponudu s ciljem poticanja aktivnosti umrežavanja među poduzećima (CSES, 2002; OECD, 2019).

Vodstvo inkubatora često koristi razinu popunjenosti inkubatora kao pokazatelj uspješnosti, međutim treba napomenuti kako maksimalna popunjenost nije optimalna iz razloga što se treba voditi računa da se poduzećima stanarima omogući prijelaz iz jedne vrste smještaja u drugi sukladno njihovim potrebama (CSES, 2002). Stoga, preporučena razina popunjenosti iznosi $80 \%$ do $90 \%$ kako bi inkubatori bili u stanju zadržati navedenu fleksibilnost (CSES, 2002). Nadalje, s obzirom da inkubatori subvencioniraju korištenje prostora, usluge subvencioniranog najma često se postavljaju na način da se s vremenom cijena najma povećava kako bi se poduzeća potaknulo na izlazak iz inkubatora ukoliko su spremna za samostalno poslovanje (OECD, 1997; Bošnjak, 2011). S druge strane, u 
nastojanju ostvarenja maksimizacije prihoda od najma, nije rijetkost da specijalizirani inkubatori nastoje postići maksimalne razine popunjenosti pri čemu primaju stanare i iz drugih poslovnih sektora. Stoga, čest je slučaj da u specijaliziranim visoko-tehnološkim inkubatorima nisu smještena samo inovativna tehnološka poduzeća, već su smještena i poduzeća iz različitih drugih sektora. Prema podacima OECD (1997) oko 35\% prostora $\mathrm{u}$ visoko-tehnološkim inkubatorima u Ujedinjenom Kraljevstvu popunjeno je poduzećima iz područja računovodstva, osiguranja i financijskih usluga. Tang i sur. (2014) također navode primjere kako sveučilišni inkubatori za visoke tehnologije u NR Kini smještaju i poduzeća stanare koji nisu sastavnice sveučilišta, a koji imaju komercijalni potencijal.

\subsection{Usluge poslovnog savjetovanja}

$\mathrm{U}$ literaturi o inkubatorima, prvotno je prevladavala usredotočenost na infrastrukturne i administrativne usluge, dok se u novije vrijeme naglasak stavlja na usluge poslovnog savjetovanja (Peters i sur., 2004.), iz razloga što poslovno savjetovanje predstavlja dodanu vrijednost smještaja u poduzetničkome inkubatoru. Usluge poslovnog savjetovanja mogu uključivati poslovnu edukaciju i treninge u različitim područjima poslovnog upravljanja, kao što su: oglašavanje, prodajne i marketinške usluge, pomoć u izradi poslovnih planova, pomoć u sudjelovanju na konferencijama i sajmovima, pristupa stručnim bazama podataka, pomoć u istraživanju i razvoju, zaštite intelektualnog vlasništva, ishođenja dozvola ili zapošljavanje (CSES, 2002; Bošnjak 2011; Batlle, 2016).

Usluge poslovnog savjetovanja najčešće se mogu podijeliti u sljedeće skupine: (i) poduzetničko obrazovanje; (ii) usluge poslovne podrške; (iii) podrška u transferu tehnologije i inovacija, te (iv) podrška u financiranju i širenju poslovanja (CSES, 2002). Inkubatori u fazi pred-inkubacije poduzećima nude podršku u izradi poslovnog plana te ostale oblike poduzetničkog obrazovanja vezano uz pokretanje poduzeća. Za realizaciju usluga poslovne podrške, za određena specijalizirana područja kao što su pravne usluge, računovodstvene usluge ili istraživanje tržišta, inkubatori mogu angažirati i vanjske pružatelje tih usluga. Poduzetnički inkubatori pružaju vlasnicima poduzeća potrebna znanja za komercijalizaciju njihovih istraživanja, pri čemu proces započinje s procjenom i odabirom stanara temeljem njihovog poslovnog plana te komercijalnim potencijalom plasmana inovacije na tržište (OECD, 1997).

Voditelji inkubatora vrlo su važni kako za uspjeh inkubatora tako i za uspjeh njegovih stanara. Voditelji sudjeluju u definiranju ciljeva inkubatora, u odabiru poduzeća stanara, pružanju podrške glede povezivanja i umrežavanja kako $\mathrm{s}$ internim tako i s eksternim akterima, te u pronalasku kvalitetnih zaposlenika (OECD, 1997). Voditelji inkubatora najčešće su zaduženi su za izgradnju kontakata s povezanim institucijama i sponzorima (OECD, 2019). Stoga, može se zaključiti kako su voditelj ili direktor inkubatora te uprava inkubatora izrazito bitni za uspjeh inkubatora, s obzirom da donose kriterije za odabir poduzeća stanara, odlučuju o pravilima poslovanja inkubatora, te odlučuju o vrsti i kvaliteti pružanja poslovnih usluga koje vrlo često mogu biti i besplatne (Bošnjak, 2011). 


\subsection{Usluge umrežavanja}

Za novoosnovana poduzeća važno je razviti mrežu kontakata sa svim relevantnim akterima koji mogu utjecati na njihovo poslovanje. Usluge umrežavanja ili povezivanja koje inkubatori osiguravaju svojim stanarima mogu se podijeliti na aktivnosti internog umrežavanja te na aktivnosti eksternog umrežavanja. Interno umrežavanje obuhvaća veze poduzeća stanara sa svim akterima unutar inkubatora, odnosno s drugim stanarima ili sa zaposlenicima inkubatora, dok se eksterno umrežavanje odnosi na kontakte izvan inkubatora, poput sveučilišta, poslovnih stručnjaka ili potencijalnih investitora (Batlle, 2016; Lesakova, 2012). Aktivnosti umrežavanja uključuju i povezivanje s financijskim akterima, odnosno pružanje pomoći u osiguravanju financiranja od strane banaka ili iz javnih fondova (Tang i sur., 2014). Također, Lesakova (2012) smatra kako su osiguranje pristupa kapitalu te pružanje financijskih savjeta jedne od osnovnih financijskih usluga koje inkubatori nude.

Inkubatori najčešće imaju ulogu povezivanja poduzeća s potencijalnim investitorima, kao što su: investitori rizičnog kapitala, privatni subjekti, poslovni anđeli i drugi (OECD, 1997; CSES, 2002; OECD, 2019). OECD (2019) navode kako je jedna od uobičajenih aktivnosti poduzetničkih inkubatora redovito organiziranje različitih događanja, kao što su radionice ili seminari kako bi se poduzeća stanari mogli sastati s investitorima, financijskim i potpornim institucijama te drugim poduzetnicima i na taj način bila u mogućnosti lakše pronaći poslovne partnere ili prikupiti potrebne financijske i tržišne informacije. Inkubatori mogu također pružiti i razne druge izvore financiranja svojim stanarima, kao što su: pružanje zajmova ili uspostavom vlastitih fondova početnog (rizičnog) kapitala namijenjenih poduzetnicima početnicima (OECD, 1997). Inkubatori također mogu uzeti i određene vlasničke udjele u zamjenu za osiguranje početnog kapitala. Primjerice u Izraelu inkubatori smiju posjedovati do 20 posto udjela u svojim poduzećima stanarima (OECD, 1997; Pace, 2001).

Smatra se kako su inkubatori uspješniji ukoliko nude veći broj usluga (Batlle, 2016). Gerlach i Brem (2015) smatraju kako su usluge koje inkubatori pružaju presudne za uspješnost inkubatora, budući da o njima ovisi uspjeh poduzeća stanara koja napuštaju inkubator. Li i sur. (2020) ustanovili su značajnu povezanost između usluga umrežavanja, poslovnog savjetovanja i financijske podrške koje pružaju inkubatori i razvoja poduzetništva. S obzirom na navedeno, ispitat će se sljedeće hipoteze:

H1: Infrastrukturne usluge koje inkubatori pružaju pozitivno utječu na uspješnost inkubatora.

H2: Financijske usluge koje inkubatori pružaju pozitivno utječu na uspješnost inkubatora.

H3: Usluge umrežavanja koje inkubatori pružaju pozitivno utječu na uspješnost inkubatora.

H4: Pravne usluge koje inkubatori pružaju pozitivno utječu na uspješnost inkubatora.

H5: Usluge upravljanja ljudskim resursima koje inkubatori pružaju pozitivno utječu na uspješnost inkubatora.

H6: Usluge poslovnog savjetovanja koje inkubatori pružaju pozitivno utječu na uspješnost inkubatora. 


\section{METODOLOGIJA ISTRAŽIVANJA}

\subsection{Model istraživanja}

Glavno istraživačko pitanje u radu je da li su potporne usluge inkubatora pozitivno povezane s uspješnošću inkubatora, te ako jesu, koje pojedinačne potporne usluge utječu na uspješnost inkubatora. Uspješnost inkubatora kao zavisna varijabla mjerena je temeljem odgovora ispitanika o tome koliko se slažu da je inkubator uspješan (Batlle, 2016; CSES, 2002; OECD, 2019; Tang i sur., 2014). Ponuđeni odgovori izražavaju se na Likertovoj ljestvici od 1 do 5, gdje je 1 = uopće se ne slažem, 2 = uglavnom se ne slažem, 3 = niti se slažem niti se ne slažem, $4=$ uglavnom se slažem, i $5=$ slažem se.

Nezavisne varijable predstavljaju usluge koje inkubatori pružaju, pri čemu je prvo ispitivana dostupnost pojedinih usluga razvrstanih u šest kategorija: infrastrukturne usluge, financijske usluge, usluge umrežavanja, pravne usluge, usluge upravljanja ljudskim resursima, te usluge poslovnog savjetovanja. Nakon čega je od ispitanika traženo da na Likertovoj ljestvici od 1 do 5 ocjene stupanj slaganja s obzirom koliko je prema njihovu mišljenju inkubator uspješan u pružanju svake od prethodno navedenih usluga. U konačnici napravljen je umnožak odgovora vezanih uz dostupnost svake pojedine usluge te njene uspješnosti.

Kao kontrolne varijable korištene su: radno mjesto ispitanika, radno iskustvo ispitanika, broj poduzeća u inkubatoru, te broj zaposlenika u inkubatoru. Radno mjesto ispitanika mjereno je na način da su ispitanicama bila ponuđena tri moguća odgovora: 'administrator', 'stručni suradnik/voditelj projekta/konzultant', te 'direktor/voditelj inkubatora'. Radno iskustvo ispitanika mjereno je na način da su ispitanicama bila ponuđena četiri moguća odgovora koja su se odnosila isključivo na trenutno radno iskustvo u promatranom inkubatoru: 'manje od 1 godine', '2 do 4 godine', '5 do 9 godina', te 'više od 10 godina'. Broj poduzeća u inkubatoru, kao kontrolna varijabla, mjerena je s pet ponuđenih odgovora: ' 1 do 5 poduzeća', ' 6 do 10 poduzeća', '11 do 15 poduzeća', '16 do 20 poduzeća', te 'više od 20 poduzeća'. Broj zaposlenika u inkubatoru kao kontrolna varijabla mjerena je s tri ponuđena odgovora: '1 do 5 zaposlenih, '6 do 10 zaposlenih', te 'više od 10 zaposlenih'.

\subsection{Uzorak i operacionalizacija istraživanja}

Uzorak istraživanja čine poduzetnički inkubatori koji su identificirani na području Republike Hrvatske, na temelju podataka iz Jedinstvenog registra poduzetničke infrastrukture $^{6}$ te na temelju podataka $s$ mrežnih stranica poduzetničkih inkubatora. Operacionalni dio istraživanja temelji se na anketnome upitniku koji je sastavljen po uzoru na istraživanja koja su proveli CSES (2002) te Batlle (2016). Anketni upitnik izrađen je u Google obrascu te je poslan na 62 e-mail adrese poduzetničkih inkubatora, pri čemu je 40 poduzetničkih inkubatora identificirano u Jedinstvenom registru poduzetničke infrastrukture, dok su 22 inkubatora koja aktivno posluju identificirana

\footnotetext{
${ }^{6}$ Jedinstveni registar poduzetničke infrastrukture vodi Ministarstvo gospodarstva i održivoga razvoja i u njemu su evidentirani subjekti poduzetničke infrastrukture $u$ RH. Dostupno na: http://reg.mingo.hr/pi/public/
} 
izvan navedenog registra. Zaprimljena su 34 odgovara od ukupno 62 inkubatora koliko ih je bilo kontaktirano, čime stopa povrata iznosi $54,8 \%$.

\subsection{Opis uzorka}

Ispitanici su u najvećem broju voditelji inkubatora ili direktori, njih 24 odnosno 70.6\%. Prema spolu, 24 (70.6\%) su ženske sudionice te je 10 (29.4\%) muških sudionika. Najviše sudionika istraživanja odnosi se na dobnu skupinu od 30 do 39 godina (41.2\%), po jednaki broj odnosi se na dobnu skupinu od 20 do 29 godina i od 40 do 49 godina (14.7\%), dok 10 sudionika (29.4\%) ima više od 50 godina. Kad se promatra obrazovna struktura sudionika, najveći broj ima više i visoko obrazovanje, njih 19 (55.9\%), dok 12 $(35.3 \%)$ ima magisterij, a $3(8.8 \%)$ ima doktorat. Prema duljini radnog staža u promatranom poduzetničkom inkubatoru, najveći broj zaposlenika ima 2 do 4 godine radnog staža, njih $13(38.2 \%), 9$ (26.5\%) ispitanika je u inkubatoru zaposleno od 5 do 9 godina, $8(23.5 \%)$ u inkubatoru radi više od 10 godina, dok $4(11.7 \%)$ ispitanika u inkubatoru radi manje od 1 godine.

\subsection{Analiza}

Za potvrdu hipoteza korištena je višestruka hijerarhijska regresija te Spearmanov koeficijent korelacije ranga. Spearmanovim koeficijentom korelacije ocijenila se povezanost promatranih varijabli s uspješnošću inkubatora. Analitički dio istraživanja obrađen je korištenjem programa SPSS koji je omogućio potpunu analizu podataka $\mathrm{s}$ ciljem što vjerodostojnije interpretacije. Također, testirane su osnovne pretpostavke višestruke regresije pri čemu se može utvrditi kako ne postoje problemi multikolinearnosti, heteroskedastišnosti, niti autokorelacije, s obzirom da su VIF vrijednosti ispod 3, Durbin-Watson statistika iznosi 1.709, te je maksimalna Cook udaljenost 0.272 .

\section{REZULTATI ISTRAŽIVANJA}

Tablice 1 do 5 prikazuju koeficijente korelacije između promatranih nezavisnih varijabli te uspješnosti inkubatora kao zavisne varijable. Iz navedenih tablice vidljivo je, sukladno izračunatim vrijednostima Spearmanovog koeficijenta korelacije ranga $\left(\mathrm{r}_{\mathrm{s}}\right)$, kako između gotovo svake pojedine usluge koju inkubatori pružaju poduzećima stanarima i uspješnosti inkubatora postoji pozitivna statistički značajna korelacija. Promatrajući infrastrukturne usluge, iz tablice 1 vidljivo je kako postoji pozitivna i srednja jaka povezanost između uspješnosti inkubatora te sljedećih infrastrukturnih usluga: pristup internetu $\left(\mathrm{r}_{\mathrm{s}}=0.61, \mathrm{p}<0.01\right)$, usluga čajne kuhinje ili kantine $\left(\mathrm{r}_{\mathrm{s}}=0.51\right.$, $p<0.01)$, soba za sastanke $\left(r_{s}=0.61, p<0.01\right)$; IT oprema i namještaj $\left(r_{s}=0.61, p<0.01\right)$; te zakup poslovnog prostora $\left(\mathrm{r}_{\mathrm{s}}=0.50, \mathrm{p}<0.01\right)$. Usluga tajništva ili recepcije, te usluga pružanja tehnoloških prostora, kao što su laboratoriji i slično, nisu statistički značajno povezani sa uspješnošću inkubatora. 
Tablica 1. Koeficijenti korelacije između infrastrukturnih usluga i uspješnosti inkubatora $(\mathrm{n}=34)$

\begin{tabular}{|l|c|}
\hline Infrastrukturne usluge & Uspješnost inkubatora \\
\hline Pristup internetu & $0.61^{* *}$ \\
\hline Usluga čajne kuhinje ili kantine & $0.51^{* *}$ \\
\hline Soba za sastanke & $0.61^{* *}$ \\
\hline IT oprema i namještaj & $0.61^{* *}$ \\
\hline Usluga tajništva ili recepcije & 0.20 \\
\hline Zakup poslovnog prostora & $0.50^{* *}$ \\
\hline Tehnološki prostori (laboratoriji i sl.) & 0.31 \\
\hline
\end{tabular}

Napomena: ${ }^{*} \mathrm{p}<0.05 ; *{ }^{*} \mathrm{p}<0.01$

Kad se promatraju koeficijenti korelacije između financijskih usluga i uspješnosti inkubatora u tablici 2, također se pokazuje kako postoji pozitivna i srednje jaka povezanost sa sljedećim financijskih uslugama: pružanje zajmova $\left(\mathrm{r}_{\mathrm{s}}=0.53, \mathrm{p}<0.01\right)$, pružanje početnog kapitala $\left(\mathrm{r}_{\mathrm{s}}=0.53, \mathrm{p}<0.01\right)$, financiranje autorskih prava $\left(\mathrm{r}_{\mathrm{s}}=0.64\right.$, $\mathrm{p}<0.01)$. Nadalje, od financijskih usluga koje pokazuju pozitivnu i relativno slabu povezanost $\mathrm{s}$ uspješnošću inkubatora su: pristup fondovima rizičnog kapitala $\left(\mathrm{r}_{\mathrm{s}}=0.43\right.$, $\mathrm{p}<0.05)$, te pristup kapitalu poslovnih anđela $\left(\mathrm{r}_{\mathrm{s}}=0.39, \mathrm{p}<0.05\right)$, pri čemu jedino usluga izrade procjene poduzeća nije statistički značajno povezana s uspješnošću inkubatora.

Tablica 2. Koeficijenti korelacije između financijskih usluga i uspješnosti inkubatora (n $=34$ )

\begin{tabular}{|l|c|}
\hline Financijske usluge & Uspješnost inkubatora \\
\hline Pristup fondovima rizičnog kapitala & $0.43^{*}$ \\
\hline Pružanje zajmova & $0.53^{* *}$ \\
\hline Pružanje početnog kapitala & $0.53^{* *}$ \\
\hline Pristup kapitalu poslovnih anđela & $0.39^{*}$ \\
\hline Financiranje autorskih prava & $0.64^{* *}$ \\
\hline Izrada procjene poduzeća & 0.20 \\
\hline
\end{tabular}

Napomena: $* \mathrm{p}<0.05 ; * * \mathrm{p}<0.01$

Vezano uz usluge umrežavanja prema dobivenim vrijednostima Spearmanovog koeficijenta korelacije i izračunatoj signifikantnosti korelacije, pokazuje se kako postoji pozitivna i srednja jaka povezanost između sljedećih usluga umrežavanja i uspješnosti inkubatora: povezivanje sa stanarima $\left(\mathrm{r}_{\mathrm{s}}=0.61, \mathrm{p}<0.01\right)$, povezivanje sa stručnjacima $\left(r_{s}=0.61, p<0.01\right)$, povezivanje sa zaposlenicima $\left(r_{s}=0.61, p<0.01\right)$, povezivanje $s$ financijskim akterima $\left(\mathrm{r}_{\mathrm{s}}=0.66, \mathrm{p}<0.01\right)$, te povezivanje $\mathrm{s}$ kontaktima iz industrije $\left(\mathrm{r}_{\mathrm{s}}=0.65, \mathrm{p}<0.01\right)$. Zanimljivo je da se jedina usluga koja nije statistički značajno povezana s uspješnošću inkubatora odnosi na povezivanje sa sveučilištima. 
Tablica 3. Koeficijenti korelacije između usluga umrežavanja i uspješnosti inkubatora (n $=34)$

\begin{tabular}{|l|c|}
\hline Usluge umrežavanja & Uspješnost inkubatora \\
\hline Povezivanje sa stanarima & $0.61^{* *}$ \\
\hline Povezivanje sa stručnjacima & $0.61^{* *}$ \\
\hline Povezivanje sa zaposlenicima & $0.61^{* *}$ \\
\hline Povezivanje sa sveučilištima & -0.10 \\
\hline Povezivanje s financijskim akterima & $0.66^{* *}$ \\
\hline Povezivanje s kontaktima iz industrije & $0.65^{* *}$ \\
\hline
\end{tabular}

Napomena: ${ }^{*} \mathrm{p}<0.05 ; * * \mathrm{p}<0.01$

Promatrajući pravne usluge i usluge upravljanja ljudskim resursima, jedino usluga koja se odnosi na pomoć u zapošljavanju pokazuje pozitivnu i jaku korelaciju s uspješnošću inkubatora $\left(\mathrm{r}_{\mathrm{s}}=0.93, \mathrm{p}<0.01\right)$. Nadalje, između usluge pomoć $\mathrm{u}$ oporezivanju i uspješnosti inkubatora postoji pozitivna i relativno slaba korelacija $\left(\mathrm{r}_{\mathrm{s}}=0.35, \mathrm{p}<0.05\right)$, dok ostale usluge nisu statistički značajno povezane s uspješnošću inkubatora.

Tablica 4. Koeficijenti korelacije između pravnih i HR usluga i uspješnosti inkubatora (n $=34)$

\begin{tabular}{|l|c|}
\hline Pravne usluge & Uspješnost inkubatora \\
\hline Pomoć pri zaštiti intelektualnog vlasništva & 0.31 \\
\hline Pomoć u oporezivanju & $0.35^{*}$ \\
\hline Pomoć pri zaštiti autorskih prava i patenata & 0.20 \\
\hline Pomoć u ishođenju dozvola & -0.04 \\
\hline Usluge upravljanja ljudskim resursima & Uspješnost inkubatora \\
\hline Pomoć pri zapošljavanju & $0.93^{* *}$ \\
\hline
\end{tabular}

Napomena: ${ }^{*} p<0.05 ; * * p<0.01$

Analizirajući usluge poslovnog savjetovanja, sljedeće četiri usluge pokazuju pozitivnu srednje jaku povezanost $\mathrm{s}$ uspješnošću inkubatora: poslovno obučavanje $\left(r_{s}=0.55, p<0.01\right)$, razvoj poslovnog plana $\left(r_{s}=0.63, p<0.01\right)$, radionice $\left(r_{s}=0.61, p<0.01\right)$, te pomoć $\mathrm{u}$ sudjelovanju na konferencijama $\mathrm{i}$ sajmovima $\left(\mathrm{r}_{\mathrm{s}}=0.63, \mathrm{p}<0.01\right)$. Usluge između kojih postoji relativno slaba i pozitivna korelacija s uspješnošću inkubatora su: pomoć $\mathrm{u}$ izradi marketinškog plana $\left(\mathrm{r}_{\mathrm{s}}=0.45, \mathrm{p}<0.01\right)$, te pristup bazama podataka $\left(\mathrm{r}_{\mathrm{s}}=0.49, \mathrm{p}<0.01\right)$. Zanimljivo je kako usluge poslovnog savjetovanja vezane uz oglašavanje i brendiranje, prodajne i marketinške usluge, te istraživanje i razvoj nisu statistički značajno povezane s uspješnošću inkubatora. 
Tablica 5. Koeficijenti korelacije između usluga poslovnog savjetovanja i uspješnosti inkubatora $(\mathrm{n}=34)$

\begin{tabular}{|l|c|}
\hline Usluge poslovnog savjetovanja & Uspješnost inkubatora \\
\hline Marketinški plan & $0.45^{* *}$ \\
\hline Baze podataka & $0.49^{* *}$ \\
\hline Oglašavanje i brendiranje & 0.32 \\
\hline Poslovno obučavanje & $0.55^{* *}$ \\
\hline Razvoj poslovnog plana & $0.63^{* *}$ \\
\hline Radionice & $0.61^{* *}$ \\
\hline Konferencije i sajmovi & $0.63^{* *}$ \\
\hline Prodajne i marketinške usluge & 0.10 \\
\hline Pomoć u istraživanju i razvoju & 0.32 \\
\hline
\end{tabular}

Napomena: $* \mathrm{p}<0.05 ; *$ * $<0.01$

Iz svega prethodno navedenog može se zaključiti kako je od ukupno 33 promatrane usluge u njih 23 pronađena pozitivna i statistički značajna korelacija sa uspješnošću inkubatora čime se potvrđuje kako su različite usluge koje inkubatori pružaju pozitivno povezane s uspješnošću inkubatora. Stoga, nakon što je utvrđena povezanost između promatranih usluga i uspješnosti inkubatora, korištenjem višestruke hijerarhijske regresije, sljedeći korak će nam dati odgovore koje sve promatrane usluge utječu na uspješnost inkubatora.

Tablica 6 daje prikaz rezultata višestruke hijerarhijske regresijske analize pri čemu je uspješnost inkubatora zavisna varijabla u oba promatrana modela. Model 1 prikazuje isključivo utjecaj kontrolnih varijabli na uspješnost inkubatora, pri čemu niti jedna promatrana varijabla nema statistički značajan utjecaj. S druge strane, model 2 pored kontrolnih varijabli promatra i utjecaj nezavisnih varijabli na uspješnost inkubatora, odnosno utjecaj pojedinih usluga koje inkubator pruža. Iz modela 2, vidljivo je kako od kontrolnih varijabli jedino broj poduzeća $(\beta=0.187, p<0.05)$ ima pozitivan i statističkih značajan utjecaj na uspješnost inkubatora što znači da bi inkubator trebao biti uspješniji kako broj poduzeća unutar inkubatora raste. Promatrajući usluge koje inkubator pruža, može se utvrditi kako isključivo financijske usluge $(\beta=0.261, p<0.05)$, te usluge umrežavanja $(\beta=0.804, p<0.01)$ imaju statistički značajan pozitivan utjecaj na uspješnost inkubatora. Stoga, može se zaključiti kako postoji dovoljno dokaza da se hipoteza H2 i hipoteza $\mathrm{H} 3$ prihvate, dok se ostale hipoteze ne mogu prihvatiti.

Tablica 6. Rezultati višestruke hijerarhijske regresijske analize $(n=34)$

\begin{tabular}{|l|c|c|}
\hline & Model 1 & Model 2 \\
\hline Kontrolne varijable & & \\
\hline Radno mjesto & $.088(.211)$ & $.197(.172)$ \\
\hline Iskustvo & $.160(.133)$ & $.026(.111)$ \\
\hline Broj poduzeća & $.102(.092)$ & $.187(.088)^{* *}$ \\
\hline Broj zaposlenika & $-.029(.170)$ & $-.033(.128)$ \\
\hline
\end{tabular}


POSLOVNA IZVRSNOST ZAGREB, GOD. XV (2021) BR. 2 Molić Milovanović B., Tutić Ž.: Utjecaj odabranih usluga hrvatskih poduzetničkih inkubatora...

\begin{tabular}{|l|l|l|}
\hline Nezavisne varijable & & \\
\hline Infrastrukturne usluge & & $-.149(.139)$ \\
\hline Usluge financiranja & & $.261(.124)^{* *}$ \\
\hline Usluge umrežavanja & & $.804(.185)^{* * *}$ \\
\hline Pravne usluge & & $-.121(.067)^{*}$ \\
\hline HR usluge & & $.047(.068)$ \\
\hline Usluge poslovnog savjetovanja & & $.050(.112)$ \\
\hline $\mathrm{R}^{2}$ & .175 & $.661 * * *$ \\
\hline Adjusted $\mathrm{R}^{2}$ & .062 & $.513^{* * *}$ \\
\hline
\end{tabular}

Napomena: signifikatnost pri ${ }^{*} \mathrm{p}<0.1,{ }^{*} \mathrm{p}<<0.05, * * * \mathrm{p}<0.01$. Standardne greške prikazane su u zagradama.

\section{ZAKLJUČNA RAZMATRANJA}

Poduzetnički inkubatori imaju važnu ulogu u pružanju podrške malim i srednjim poduzećima kako na lokalnoj tako i na regionalnoj razini. Navedeno se posebice odnosi na pružanje podrške poduzetnicima početnicima koji predstavljaju ciljanu skupinu poduzetničkih inkubatora. Poduzetnički inkubatori nude široki spektar usluga, te su u svome razvoju napredovali od pukog pružanja usluge najma poslovnog ili radnog prostora do pružanja cijelog niza specijaliziranih usluga poduzećima stanarima ovisno o fazi u kojoj se njihovo poslovanje nalazi. Dakle, smještaj u poduzetničkome inkubatoru za osnovni cilj ima svojim stanarima značajno unaprijediti izglede daljnjeg opstanka na tržištu.

Istraživanje je pokazalo kako isključivo financijske usluge, te usluge umrežavanja imaju pozitivan utjecaj na uspješnost inkubatora, te kako postoji značajna povezanost između promatranih 23 od 32 usluge koje inkubatori pružaju i uspješnosti inkubatora. Točnije, za uspješnost inkubatora značajno je njihovo pružanje infrastrukturnih usluga, među kojima su: pristup internetu, usluge čajne kuhinje ili kantine, sobe za sastanke, IT oprema i namještaj, te zakup poslovnog prostora. Od financijskih usluga, značajno su povezane usluge pristupa fondovima rizičnog kapitala, pružanje zajmova, pružanje početnog kapitala, pristup kapitalu poslovnih anđela, te usluga financiranja autorskih prava. Nadalje, od usluga umrežavanja, povezivanje sa stanarima, povezivanje sa stručnjacima, povezivanje sa zaposlenicima inkubatora, povezivanje s financijskim akterima, te povezivanje s kontaktima iz industrije značajno su povezane sa uspješnošću inkubatora. Za uspješnost inkubatora značajno je i njihovo pružanje pravnih usluga i usluga upravljanja ljudskim resursima, među kojima se ističu pomoć u oporezivanju i pomoć pri zapošljavanju. Naposljetku, sa uspješnošću inkubatora značajno su povezane sljedeće usluge poslovnog savjetovanja: izrada marketinškog plana, pristup bazama podataka, poslovno obučavanje, razvoj poslovnog plana, radionice, te pomoć pri odlasku na konferencije i sajmove. 


\subsection{Teorijske i praktične implikacije istraživanja}

Rezultati provedenog istraživanja u skladu su sa istraživanjem koje je provela Batlle (2016) gdje je također potvrđena pozitivna veza između određenih usluga i uspješnosti inkubatora. Gerlach i Brem (2015) također su pronašli značajnu povezanost između pojedinih usluga i uspjeha inkubatora, posebice u uslugama koje se odnose na transfer tehnologije, pomoć u istraživanju i razvoju, te poslovno i pravno savjetovanje. Li i sur. (2020) također su ustanovili važnost usluga umrežavanja, poslovnog obučavanja i financijske podrške za razvoj poduzetništva.

U praktičnome smislu ovo istraživanje može poslužiti voditeljima inkubatora budući da je pružen pregled osnovnih usluga koje inkubatori pružaju, te je ustanovljena povezanost i utjecaj s uspješnošću inkubatora. Stoga, pored prethodno detaljno navedenih usluga, osnivači i voditelji inkubatora trebaju staviti veći naglasak na financijske usluge te na usluge umrežavanja kao osnovnih pokretača uspješnosti inkubatora.

\subsection{Ograničenja istraživanja}

S ciljem postizanja veće valjanosti rezultata, poželjno bi bilo uključiti veći uzorak $\mathrm{u}$ istraživanju s obzirom da je ukupan uzorak na kojem je provedeno istraživanje obuhvatilo samo 34 inkubatora. U istraživanje su bili uključeni isključivo voditelji inkubatora, dok poduzeća stanari inkubatora nisu bili obuhvaćeni, stoga bilo bi korisno istražiti i njihovu percepciju uspješnosti inkubatora u odnosu na promatrane varijable. Nadalje, uspješnost inkubatora ispitana je isključivo subjektivnom percepcijom ispitanika, te bi u narednim istraživanjima bilo korisno promatrati uspješnost i pomoću određenih sekundarnih kvantitativnih pokazatelja, kao što su površina inkubatora, prihodi inkubatora, broj stvorenih radnih mjesta, stopa preživljavanja inkubiranih poduzeća (CSES, 2002; Tang i sur., 2014), dok se ovo istraživanje usredotočilo na načine na koje inkubatori organiziraju i upravljaju procesima inkubacije (Bergek i Norman, 2008).

\section{LITERATURA:}

1. Abduh, M., D'Souza, C., Quazi, A., \& Burley, H. T. (2007). Investigating and classifying clients' satisfaction with business incubator services. Managing Service Quality: An International Journal.

2. Batlle, S. M. (2016). Performance of Business incubators: the stakeholders perspective. Tecnico Lisboa, Master thesis.

3. Bergek, A., \& Norrman, C. (2008). Incubator best practice: A framework. Technovation, 28(1-2), 20-28.

4. Bošnjak, S. (2011). Poslovni inkubatori kao generatori razvoja poduzetništva. Praktični menadžment: stručni časopis za teoriju i praksu menadžmenta, 2(2), 51-56.

5. Centre for Strategy \& Evaluation Services. (2002). Benchmarking of business incubators. CSES. 
6. Gerlach, S., \& Brem, A. (2015). What determines a successful business incubator? Introduction to an incubator guide. International Journal of Entrepreneurial Venturing, 7(3), 286-307.

7. Lesakova, L. (2012). The role of business incubators in supporting the SME start-up. Acta Polytechnica Hungarica, 9(3), 85-95.

8. Li, C., Ahmed, N., Qalati, S. A., Khan, A., \& Naz, S. (2020). Role of business incubators as a tool for entrepreneurship development: the mediating and moderating role of business start-up and government regulations. Sustainability, 12(5), 1822.

9. Mijačić, D. (2011). Analysis of business support infrastructure in the Republic of Serbia. National Agency for Regional Development.

10. Mulolli, E., Islami, X., \& Skenderi, N. (2017). Business Incubators as a Factor for the Development of SMEs in Kosovo. Mulolli, E., Islami, X., \& Skenderi, (2017), 659-666.

11. OECD (1997) Technology Incubators: Nurturing Small Firms Paris: OECD Publishing

12. OECD $\mid$ European Commission. (2019). Policy brief on incubators and accelerators that support inclusive entrepreneurship.

13. Pace, G. (2001). The role of development agencies for the entrepreneurial promotion: Israeli case studies. European Regional Science Association, (41).

14. Peters, L., Rice, M., \& Sundararajan, M. (2004). The role of incubators in the entrepreneurial process. The Journal of Technology Transfer, 29(1), 83-91.

15. Rice, M. P. (2002). Co-production of business assistance in business incubators: an exploratory study. Journal of business venturing, 17(2), 163-187.

16. Sarwono, R., \& Trisetyarso, A. (2017, May). Business incubator indicator service performance-A systematic literature review. In 2017 International Conference on Applied Computer and Communication Technologies (ComCom) (pp. 1-5). IEEE.

17. Sofouli, E., \& Vonortas, N. S. (2007). S\&T Parks and business incubators in middle-sized countries: the case of Greece. The Journal of Technology Transfer, 32(5), 525-544.

18. Tang, M. F., Lee, J., Liu, K., \& Lu, Y. (2014). Assessing government-supported technology-based business incubators: evidence from China. International Journal of Technology Management, 65(1-4), 24-48.

19. Tupek, K. L., \& Ćrić, G. (2018). Utjecaj poduzetničkih inkubatora na generiranje ideja i uspjeh start-up projekata u Hrvatskoj. Obrazovanje za poduzetništvo-E4E: znanstveno stručni časopis o obrazovanju za poduzetništvo, $8(1), 125-152$.

20. Van Weele, M., van Rijnsoever, F. J., \& Nauta, F. (2017). You can't always get what you want: How entrepreneur's perceived resource needs affect the incubator's assertiveness. Technovation, 59, 18-33.

21. Wang, H., Lin, D., Yin, H., Lu, Q., \& Cheng, H. (2008, September). Linking incubator services to the performance of incubated firms: A review. In 2008 4th 
POSLOVNA IZVRSNOST ZAGREB, GOD. XV (2021) BR. 2 Molić Milovanović B., Tutić Ž.: Utjecaj odabranih usluga hrvatskih poduzetničkih inkubatora...

IEEE International Conference on Management of Innovation and Technology (pp. 894-899). IEEE. 


\title{
THE IMPACT OF SELECTED SERVICES OF CROATIAN BUSINESS INCUBATORS ON THEIR PERFORMANCE
}

\author{
Bojan Morić Milovanović \& Željka Tutić
}

\begin{abstract}
Summary
Business incubators are business support institutions that aim to provide support to small and medium-sized enterprises, especially to start-ups. Most often they are formed as the result of the initiatives at the local and regional level, and established as companies which are owned by the local and regional government bodies. Given the prevalence of incubators and their role in economic development, it is important to investigate the performance of incubators in performing their tasks and whether they meet the main objectives for which they were initially established. Business incubators offer various services to their tenant companies, such as: subsidized rent for office space, business consulting services, networking services, and facilitating access to funding sources, where it has been determined that these services are positively related to the performance of the business incubators. Therefore, the aim of this paper is to evaluate the impact of selected services on the performance of business incubators in the Republic of Croatia by using multiple hierarchical regression analysis and Spearman's rank correlation coefficient. The results confirm the positive correlation for most of the services with performance, however, only financial services and networking services have a direct positive effect on the performance.
\end{abstract}

Keywords: business incubator; business support institutions; start-up entrepreneurs; incubator services; performance. 